\title{
ANALYSIS OF ACCOUNTING INFORMATION SYSTEM DISTRIBUTION OF BOP RA FUND (CASE STUDY ON RA PERWANIDA KARANGREJO 02)
}

\author{
${ }^{1}$ Nur Ika Mauliyah, ${ }^{2}$ Dwinda Agus Prastiwi \\ Institut Agama Islam Negeri Jember \\ Email:nurikamauliyah@gmail.com
}

\section{Kata kunci:}

Accounting Information System,

BOP RA and

Fund Disbursement

\section{Keywords:}

Accounting Information System, BOP RA and

Fund Disbursement

\footnotetext{
${ }^{1}$ Nur Ika Mauliyah, ${ }^{2}$ Dwinda Agus Prastiwi. (2019). Analysis Of Accounting Information System Distribution Of Bop Ra Fund (Case Study On Ra Perwanida Karangrejo 02)

Akuntabilitas: Jurnal Ilmu-Ilmu Ekonomi, 12(1), 95-104.

https://doi.org/10.35457/akuntabilit as.v12i1.720
}

\begin{abstract}
ABSTRAK
Tujuan penelitian ini adalah untuk menganalisa sistem informasi akuntansi penyaluran dana BOP RA, sudah terdapatnya sistem informasi akuntansi dalam penyaluran dana BOP RA sebagaimana sistem informasi akuntansi sudah berjalan efektif sebagi penyedia informasi. Objek penelitian ini adalah RA Perwanida Karangrejo 02, dengan melakukan analisis sistem informasi akuntansi dilakukan terhadap penyaluran dana BOP RA.

Penelitian ini menggunakan metode deskripstif kualitatif yaitu menguraikan secara menyeluruh terhadap pelaksanaan sistem informasi akuntansi yang diterapkan pada sekolah RA Perwanida Karangrejo 02 dan dibandingkan dengan petunjuk teknis serta teori-teori yang berhubungan dengan sistem informasi akuntansi, sehingga dapat dihasilkan hasil yang diinginkan peneliti.

Hasil penelitian ini menunjukkan bahwa sistem informasi akuntansi penyaluran dana BOP RA sudah sesuai dengan acuan dan aturan akan tetapi belum terbentuknya flowchart.
\end{abstract}

\section{ABSTRACT}

The purpose of this study is to analyze the accounting information system of $B O P R A$ funds distribution, the existence of accounting information system in the distribution of funds BOP RA as accounting information system has been run effectively as a provider of information. Analyzing the accounting information system conducted on the distribution of BOP RA funds.

This research uses descriptive qualitative method that describes thoroughly to the implementation of accounting information system applied at school RA X and compared with technical guidance as well as theories related to accounting information system, so that it can produce result desired by researcher.

The results of this study indicate that the accounting information system channeling BOP RA funds are in conformity with the reference and rules but not yet the formation of flowchart.

\section{PENDAHULUAN}

Raudlatul Athfal (RA) adalah lembaga pendidikan anak usia dini yang diselenggarakan melalui jalur formal. Dalam Undang-undang Sistem Pendidikan 
Nasional Nomor 20 Tahun 2003 Bab VI Pasal 28 ayat 3 disebutkan sebagai berikut :

"Pendidikan anak usia dini pada jalur formal berbentuk Taman Kanak-kanak (TK), Raudlatul Athfal (RA) atau bentuk lainnya yang sederajat sedangkan PAUD diluar jalur pendidikan formal adalah antara lain play group, TPA, TPQ, dan sejenisnya.

Sesuai dengan tuntutan kebutuhan pendidikan yang semakin berkembang dan adanya berbagai keterbatasan yang dimiliki RA sebagai lembaga layanan pendidikan anak usia dini, maka Direktorat Jenderal Pendidikan Islam melalui Direktorat Pendidikan Madrasah mengambil langkah kongkrit dengan cara memberikan BOP RA. Program ini mulai diterapkan sejak tahun 2015 dengan sasaran seluruh peserta didik pada tingkat TK atau RA. BOP adalah program pemerintah berupa pemberian dana langsung kepada RA yang besarnya dihitung berdasarkan jumlah siswa pada masing-masing RA. BOP ini berkontribusi besar untuk memaksimalkan manfaat sistem informasi sebagai bahan olah bagi keputusan manajerial pihak sekolah. Keputusan yang tepat dan cepat akan memberikan dampak signifikan terhadap kemampuan kemajuan pendidikan. Berdasarkan latar belakang yang dipaparkan di atas, maka perlu adanya pembatasan masalah sehingga penelitian yang dilakukan bisa lebih fokus dalam menggali masalah pada analisis sistem informasi akuntansi penyaluran dana BOP.

\section{Informasi Akuntansi}

Menurut Tata Sutabri (2004 : 6) mendefinisikan sistem informasi akuntansi sebagai kumpulan sumber daya, seperti manusia dan peralatan yang diatur untuk mengubah data menjadi informasi.

Menurut Haryono Jusup (2011 : 481-482) sistem informasi akuntansi mengumpulkan dan mengolah data transaksi serta mengkomunikasikan informasi keuangan kepada para pengambil keputusan. Sistem Informasi Akuntansi yang efisien dan efektif didasarkan pada prinsip-prinsip tertentu yaitu hemat, bermanfaat dan fleksibel. 


\section{Bantuan Operasional Pendidikan Raudlatul Athfal}

BOP RA adalah program pemerintah berupa pemberian dana langsung kepada RA yang besarnya dihitung berdasarkan jumlah siswa pada masing-masing RA.

BOP RA merupakan biaya penyelenggaraan dan/atau pengelolaan pendidikan RA yang dapat digunakan oelh RA untuk memenuhi kebutuhan biaya operasional nonpersonalia dan personalia. Secara detail jenis kegiatan yang boleh dibiayai dari dana BOP RA dibahas pada bagian penggunaan dana BOP RA.

\section{1) Tujuan BOP RA}

Secara umum program BOP RA bertujuan untuk mewujudkan layanan pendidikan yang terjangksu dan bermutu bagi semua lapisan masyarakat dalam rangka mendukung Program PAUD. Secara khusus program BOP bertujuan untuk :
a. Membantu biaya operasional RA
b. Mengurangi angka putus sekolah pada RA
c. Meningkatkan angka partisipasi kasar (APK) siswa RA
d. Mewujudkan keberpihakan pemerintah (affirmative action) bagi siswa RA dari keluarga tidak mampu dengan membantu (discount free) tagihan biaya sekolah

e. Memberikan kesempatan yang setara (equal opportunity) bagi siswa kurang mampu pada RA untuk mendapatkan layanan pendidikan yang terjangkau dan bermutu

\section{2) Sasaran Program dan Besar Bantuan BOP RA}

Sasaran program BOP RA adalag semua RA di seluruh Indonesia yang telah memiliki izin operasional. Besar biaya satuan BOP yang diterima oleh RA dihitung berdasarkan jumlah siswa per RA dengan besaran RP 300.000,00/siswa/tahun. Jumlah besaran tersebut disalurkan dalam satu periode.

\section{3) Waktu Penyaluran Dana BOP RA}

Dana BOP diberikan selama satu tahun untuk periode Januari sampai Desember, dengan mekanisme pencairan satu kali tahapan atau lebih dalam setahun. 


\section{METODE PENELITIAN}

Menurut Anwar Sanusi (2014 : 105), metode pengumpulan data dapat dilakukan dengan beberapa cara, seperti cara survei, cara observasi, dan cara dokumentasi.

a. Cara Survei

Cara survei merupakan cara pengumpulan data dimana peneliti atau pengumpul data mengajukan pertanyaan atau pernyataan kepada responden baik dalam bentuk lisan maupun secara tertulis. Jika pernyataan diajukan dalam bentuk lisan maka dinamakan wawancara, sedangkan diajukan secara tertulis disebut kuesioner. Berkaitan dengan itu, cara survei terbagi menjadi dua bagian yaitu wawancara (interview) dan kuesioner.

b. Cara Observasi

Observasi merupakan cara pengumpulan data melalui proses pencatatan perilaku subjek (orang), objek (benda) atau kejadian yang sistematik tanpa adanya pertanyaan atau komunikasi dengan individuindividu yang diteliti. Observasi meliputi segala hal yang menyangkut pengamatan aktivitas atau kondisi perilaku maupun nonperilaku. Observasi nonperilaku meliputi catatan (record), kondisi fisik (physical condition), dan proses fisik (physical process). Sedangkan observasi perilaku terdiri atas nonverbal, bahasa (linguistic) dan ekstra bahasa (extralinguistic).

c. Cara Dokumentasi

Cara dokumentasi biasanya dilakukan untuk mengumpulkan data sekunder dari berbagai sumber, baik secara pribadi maupun kelembagaan. Pada umumnya, data yang diperoleh dengan cara dokumentasi masih sangat mentah karena antara informasi yang satu dengan yang lainnya tercerai berai, bahkan kadang kala sulit untuk dipahami apa maksud yang terkandung pada data tersebut. Untuk itu, peneliti harus mengatur sistematika data tersebut sedemikian rupa dan meminta informasi lebih lanjut kepada pengumpul data pertama. 
Metode penelitian yang digunakan dalam laporan ini adalah deskriptif kualitatif. Dimana hal ini akan mempermudah peneliti dlaam melakukan penelitian karena berhubungan langsung dengan sumber informasi.

\section{HASIL DAN PEMBAHASAN}

\section{Sistem Informasi Akuntansi RA Perwanida Karangrejo 02}

Fungsi yang terkait dari penyaluran dana BOP RA Perwanida Karangrejo 02 ini adalah Tim Manajemen Bantuan Operasional Pendidikan Raudlatul Athal (BOP RA), Kantor Kementerian Agama Kabupaten / Kota (Kankemenag kab / kota), Kantor Wilayah Pusat (Kanwil Pusat), serta Bank BRI. Dalam melakukan peyaluran dana ini, pihak Kanwil Pusat melakukan kerjasama dengan pihak Bank BRI. Berikut adalah tahapan-tahapan dari pendaftaran penyaluran dana BOP RA, yaitu :

1) Tim manajemen BOP RA Perwanida Karangrejo 02 memulainya dengan mengisi data Education Management Information System (EMIS) terlebih dahulu. Kemudian EMIS dikirim ke Kankemenag kab / kota.

2) Kankemenag kab / kota menerima EMIS kemudian mengecek EMIS apakah sudah sesuai dengan standar yang ada. Kemudian kankemenag menyetujui EMIS apabila sudah sesuai dan dikirimkan ke kanwil pusat, dan mengembalikan EMIS kepada Tim Manajemen BOP RA untuk dikoreksi dan dilengkapi apabila kankemenag tidak menyetujui.

3) Kanwil pusat menerima EMIS dari kankemenag kab / kota, kemudian dari EMIS tersebut dibuat dan diterbitkan Petunjuk Teknis (juknis) untuk panduan sekolah-sekolah mengisi keperluan apa saja yang dibutuhkan. Juknis tersebut kemudian dikirimkan kepada kankemenag kab / kota.

4) Setelah menerima juknis dari kanwil pusat, kankemenag mengundang dan melakukan sosialisasi BOP RA dengan sekolah-sekolah yang nantinya mendapat dana BOP RA. Kemudian membagikan juknis kepada sekolah atau tim manajemen BOP RA.

5) Tim manajemen BOP RA menerima juknis kemudian mengisi juknis sesuai yang ada dengan timnya. Kemudian setelah diisi, timbulllah Lembar Pertanggungajawaban (LPJ) rangkap 2. Lembar 1 diarsip sesuai 
tanggal oleh tim manajemen BOP RA, lembar 2 dikirimkan kepada

kankemenag kab / kota. (Isi dari LPJ dapat dilihat pada lampiran 2)

6) Kankemenag menerima LPJ lembar 2 dari tim manajemen BOP RA, kemudian melakukan cek. Apabila tidak disetujui maka dikembalikan ke sekolah untuk dikoreksi dan dilengkapi, dan apabila disetujui makan LPJ lembar 2 dikirim ke kanwil pusat.

7) Kanwil pusat menerima LPJ lembar 2 dari kankemenag, kemudian mencocokkan dengan data EMIS yang telah dikirimkan terlebih dahulu. Apabila sudah dicocokkan maka kanwil pusat menetapkan data alokasi dana BOP RA yang diperoleh tiap sekolah. Kemudian data alokasi dana dikirimkan ke Bank BRI untuk diproses pencairannya. Pengiriman data alokasi dana BOP RA ke Bank BRI disertai dengan nomor rekening dan uang yang akan dikirim.

8) Pihak Bank BRI menerima data alokasi dana BOP RA berserta nomor rekening dan uang kemudian melakukan transfer ke tiap sekolah sesuai dengan data dan sesuai dengan jumlah dana yang telah ditetapkan oleh kanwil pusat yang kemudian menerbitkan rekening koran. Yang diberikan kepada tim manajemen BOP RA.

9) Tim manajemen BOP RA menerima rekening koran beserta uang. Kemudian rekening koran tersebut diarsip dengan LPJ lembar 1.

Gambar 1.2 berikut adalah flowchart penyaluran dana BOP RA Perwanida Karangrejo 02. 


\section{Gambar 1}

Sistem Informasi Akuntansi Penyaluran Dana BOP RA

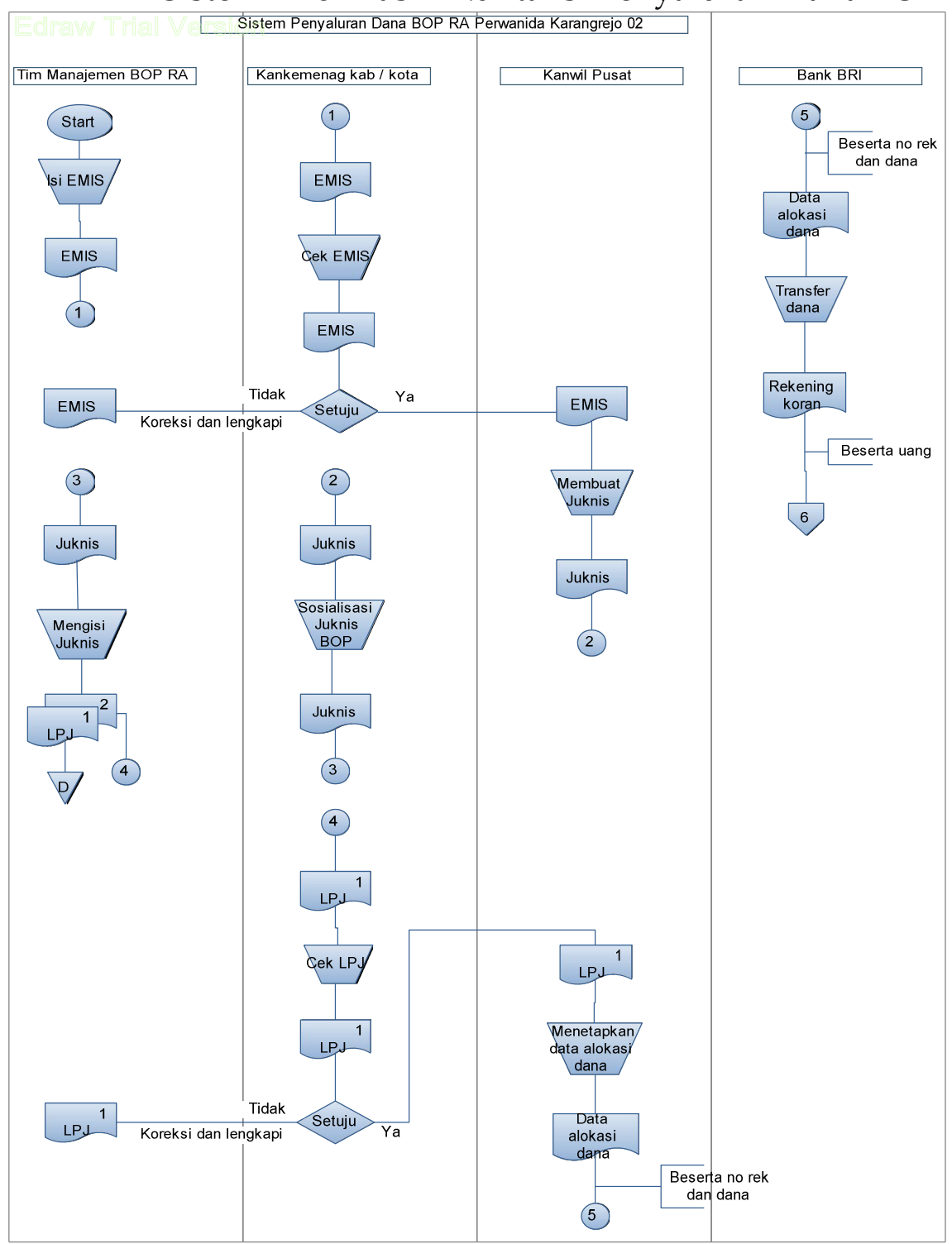

Lanjutan gambar 1.

Gambar 2

Lanjutan Sistem Informasi Akuntansi Penyaluran Dana BOP RA

\begin{tabular}{|l|l|l|l|}
\hline Tim Manajemen BOP RA & Kankemenag kab/kota & & \\
\hline & & & \\
\hline
\end{tabular}

Sumber : Data Internal RA Perwanida Karangrejo 02

Analysis of Accounting Infromation System Distribution of BOP RA Fund )Cash Study on RA Perwanida Karangrejo 02) https:// doi.org/10.35457/akuntabilitas.v12i1.720

(C) 2019 Akuntabilitas: Jurnal Ilmu-Ilmu Ekonomi. Semua hak cipta dilindungi undang-undang 


\section{Evaluasi Sistem Informasi Akuntansi Penyaluran Dana BOP RA pada RA}

\section{Perwanida Karangrejo 02}

Berdasarkan prosedur yang telah dijelaskan diatas, dapat dilihat dokumen yang digunakan dalam sistem penyaluran dana BOP RA Perwanida Karangrejo 02 sudah cukup memadai. Hal tersebut dapat dilihat dari dokumen yang digunakan dalam transaksi penyaluran dana BOP RA. Yaitu data EMIS, laporan pertanggungjawaban (LPJ) dan juga rekening koran.

Fungsi-fungsi yang terkait dalam sistem informasi akuntansi penyaluran dana BOP RA adalah :

a. Tim manajemen BOP RA. Fungsi ini adalah untuk melakukan diskusi tentang EMIS dan juga LPJ; menerima dan mengambil dana BOP RA beserta rekening koran,

b. Kankemenag kab / kota. Fungsi ini adalah tempat pelayanan dan pemeriksaan serta pengambil keputusan untuk memilih sekolah mana yang akan mendapatkan dana BOP RA dan mengecek kesesuaian dana yang disalurkan,

c. Kanwil pusat. Fungsi ini adalah melakukan alokasi dana BOP RA yang akan disalurkan ke penerima dana sesuai data EMIS,

d. Bank BRI. Fungsi ini bertanggung jawab atas penyaluran dana BOP RA kapada penerima dana BOP RA.

Lembar pertanggungjawaban (LPJ) ini merupakan hasil pengerjaan yang sesuai dengan juknis. Yaitu berisi :

a. Cover

b. Surat Keputusan Kepala Raudlatul Athfal Perwanida Karangrejo 02 yang ditanda tangani oleh Kepala RA

c. Susunan Tim Manajemen BOP RA Perwanida Karangrejo 02

d. Surat Kerjasama yang ditandatangani untuk dan atas nama kankemenag kab / kota Blitar dan juga Kepala RA

e. Data Lembaga yang diambil dari data EMIS

f. Lembar pengesahan pelaporan 
g. Kata Pengantar

h. Daftar Isi

i. Pendahuluan

j. Rincian Rencana Kegiatan Anggaran RA

k. Buku kas umum

1. Kwitansi pembayaran

m. Kwitansi / bukti pembayaran

n. Nota

o. Buku pembantu kas

p. Penutup dan saran

q. Surat pernyataan pengiriman nomor rekening RA

r. Surat pernyataan tanggung jawab mutlak

s. Surat pernyataan penyelesaian pekerjaan

t. Surat pernyataan penyimpanan dokumen

u. Kwitansi / bukti penerimaan

\section{KESIMPULAN}

Berdasarkan pembahasan di atas, maka disimpulkan bahwa RA Perwanida Karangrejo belum memiliki sistem informasi akuntansi atas penyaluran dana BOP RA dimana pelaksanaan rancangan sistem informasi akuntansi atas penyaluran dana BOP RA sudah memadai, hanya saja belum terbentuk rancangan flowchart pada sistem informasi akuntansinya. Selanjutnya evaluasi sistem informasi akuntansi yang dihasilkan untuk membantu RA Perwanida Karangrejo 02 membuat perancangan flowchart dan memperbaiki sistem informasi akuntansi sehingga sesuai dengan prinsip-prinsip penyaluran dana BOP RA sehingga tersedia informasi yang akurat dan cukup memadai untuk laporan pertanggungjawaban.

\section{DAFTAR PUSTAKA}

Baridwan, Zaki. 2008. Intermediate Accounting Edisi Kedelapan.Yogyakarta: BPFE

Bastian, Indra. 2006. Akuntansi Pendidikan. Jakarta : Erlangga

Data internal RA Perwanida Karangrejo 02 
Hamiyah, Nur dan Jauhar, Muhammad. 2015. Pengantar Manajemen Pendidikan $\quad D i$

Sekolah. Jakarta : Prestasi Pustakaraya

Haryono, Al. Jusup. 2011. Dasar-dasar Akuntansi. Yogyakarta: Sekolah Tinggi Ilmu Ekonomi YKPN

Kieso, Donald E. dan Jerry J. Weygandt. Intermediate Accounting. 12nd Edition. New York: John Wiley \& Sons, 2007

M. Sadeli, Lili. 2002. Dasar-dasar Akuntansi. Jakarta: Bumi Aksara

Mc Leod, Raymond. 2001. Sistem Informasi Manajemen. Terjemahan Hari

Petunjuk Teknis BOP RA Tahun 2017, hlm. 1

TMbooks. 2013. Sistem Informasi Akuntansi - Konsep dan Penerapan. Yogyakarta ANDI 